\title{
Elicitor induced increased rosmarinic acid content of in vitro root cultures of Ocimum basilicum L. (Sweet Basil)
}

\author{
Trayee Biswas \\ Bangabasi Morning College, 19, Rajkumar Chakraborty Sarani, Kolkata 700 009, India \\ *Email: trayeebsws@gmail.com
}

\section{ARTICLE HISTORY}

Received: 29 November 2019

Accepted: 30 January 2020

Published: 01 April 2020

\section{KEYWORDS}

Elicitor; HPLC; in vitro; methyl jasmonate; Ocimum basilicum; phenol; root culture; Rosmarinic acid

\begin{abstract}
In vitro root cultures provide an alternative means for producing secondary metabolites of pharmaceutical and industrial importance. The present investigation is an attempt to study the effect of methyl jasmonate (MeJA) as an elicitor, on the production of rosmarinic acid through in vitro root cultures of Ocimum basilicum L. The rosmarinic acid is a preformed constitutively accumulated defense compound having several biological activities including antibacterial, antiviral, and antioxidative activity. Uniform progeny of $O$. basilicum L. was obtained through in vitro shoot bud multiplication as reliable source of explants. In vitro root cultures were established in one fourth strength of Murashige and Skoog (MS) liquid medium supplemented with $1.0 \mathrm{mg} \mathrm{I}^{-1}$ a-napthaleneacetic acid (NAA). Methyl jasmonate, was supplemented to the root cultures at different concentrations $(0.01,0.1$ and $1.0 \mathrm{mM})$, and their effect on total phenol content as well as rosmarinic acid production was studied. Rosmarinic acid was quantified by high performance liquid chromatography (HPLC). Compared to the control set of cultures 1.60 fold increase in rosmarinic acid concentration ( $4.05 \pm 0.74 \%$ of dry wt) was observed in elicitor treated cultures.
\end{abstract}

\section{Introduction}

Ocimum basilicum $\mathrm{L}$. has been used as traditional medicine for household remedy against various human ailments from antiquity. It is native to tropical Asia. It is widely distributed and naturalized throughout tropical and subtropical parts of Asia, Africa and America $(1,2)$. This plant is a rich source of phenolic compounds including rosmarinic acid. Recent interest on $O$. basilicum L. has resulted from its inhibitory activity against HIV-1 reverse transcriptase (3) and chemo preventive potential due to the presence of rosmarinic acid (4). The antioxidant activity of rosmarinic acid is also reported to be correlated with the scavenging action against radicals $(5,6)$. The objective of the present study is to investigate the influence of an elicitor Methyl jasmonate (MeJA), on the biomass content and intracellular accumulation of phenolic including rosmarinic acid in root cultures of $O$. basilicum L. and to establish an optimal culture condition for increased as well as continuous rosmarinic acid production.
MeJA a fragrant volatile compound initially identified from flowers of Jasminum grandliflorum has been used as effective elicitor in several experiments for rosmarinic acid production $(7,8,9)$. Elicitation is recognized as the most practically feasible strategy for increasing the production of desirable secondary compounds from cell, organ and plant systems. Elicitor may be defined as a substance for stress factors which, when applied in small quantity to a living system, it induces or improves the biosynthesis of specific compound which do have an important role in the adaptations of plants to a stressful conditions" (10). MeJA, are a family of cyclopentanone compounds that modulate a wide range of plant responses which are typically manifested by the elicitation of secondary metabolite biosynthesis when plants face particular environmental stresses (11). Total phenolic compounds and anti oxidant activity of $O$. basilicum L. plants were significantly induced by the MeJA treatment because of the significant induction of rosmarinic acid $(7,12)$. It has also been reported an accumulation of $33.0 \pm 0.57 \mathrm{mg} \mathrm{GAE} \mathrm{g}^{-1} \mathrm{DW}$ phenolic

\footnotetext{
(c) Biswas (2020). This is an open-access article distributed under the terms of the Creative Commons Attribution License, which permits unrestricted use, distribution,
} and reproduction in any medium, provided the original author and source are credited (https://creativecommons.org/licenses/by/4.0/).

To cite this article: Biswas T. Elicitor induced increased rosmarinic acid content of in vitro root cultures of Ocimum basilicum L. (Sweet Basil). Plant Science Today. 20207(2):157-163. https://doi.org/10.14719/pst.2020.7.2.690 
content in cell cultures of $O$. basilicum L. when treated with $25 \mu \mathrm{M}$ MeJA (13). O. basilicum L. is a plant of high pharmaceutical importance, however, its constituents vary greatly in wild population because of cross pollination and high heterozygosity (14). Ocimum species are propagated conventionally by seed germination and this plant cannot be vegetatively propagated $(1,15)$. Moreover, in rural areas, utilization of wild populations as crude drugs is a regular practice for treatment of headaches, coughs, diarrhoea, constipation, warts, worms and kidney malfunction $(16,17)$. In addition, the pharmaceutical industries also make indiscriminate exploitation of this plant for their own interests hence led to depletion in the wild. In vitro shoot and root cultures have been focused as alternatives for the stable production of secondary metabolites. In vitro propagation of plants is a potentially viable system for both conservation of the plant species as well as commercial production of metabolites without the influence of seasonal variations (18). Elicitation of in vitro cultures is a useful approach for enhancing and extending production of desirable products (19) within shorter production times (20). The present study describes establishment of uniform progeny of the plant through in vitro shoot bud multiplication and root culture with high rosmarinic acid content triggered and activated by an elicitor, the signal compound of plant defense responses.

\section{Material and Methods}

\section{Materials}

Apical shoot buds from in vitro germinated seedlings (21 days after germination) of $O$. basilicum L. (sweet basil) were used as explants for in vitro shoot bud multiplication (Fig. 1b-c). Seeds were collected from Sutton and Sons (India) Pvt Ltd, Kolkata having accession number 1867 72. The plants grown from seeds were maintained in the experimental garden, Department of Botany, University of Calcutta, for in vivo studies (Fig. 1a). Voucher specimens of the species was deposited in the herbaria of University of Calcutta, (CUH, Kolkata) bearing accession numberWest Bengal, Kolkata, Ballygunge Science College,

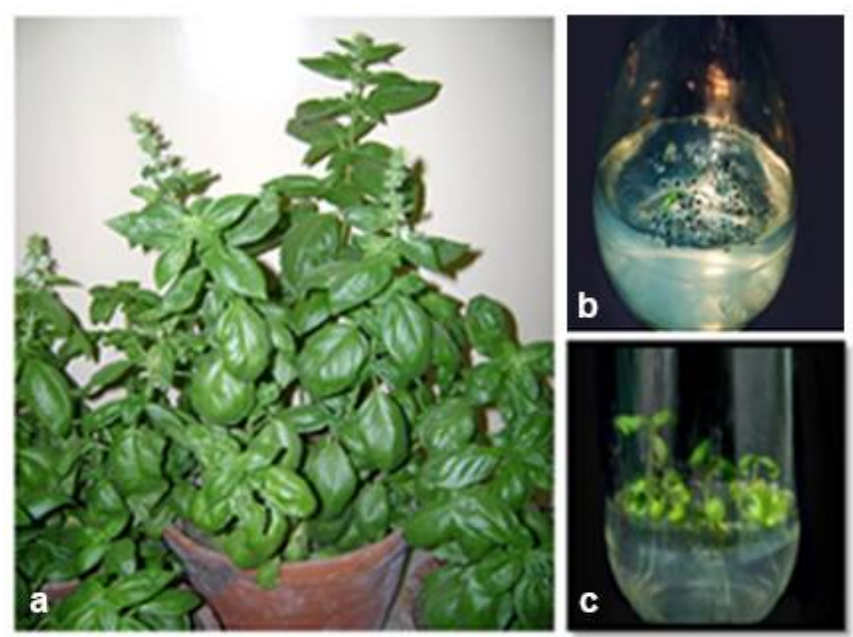

Fig. 1. a. Mature plants of $O$. basilicum L. (In vivo) (c.a. x 0.78); b. In vitro seed germination in MS basal medium (c.a. x 0.52 ); c. In vitro germinated seedlings of 0 . basilicum L. (21 days after germination) (c.a. x 0.48)
Experimental Garden, date 22.09.10, Biswas 001, Acc. no 20009 (CUH).

\section{Surface Sterilization}

Seeds of $O$. basilicum L. were first washed in aqueous liquid detergent solution (Tween 20, SRL; two drops in $100 \mathrm{ml}$ ) for $12 \mathrm{~min}$ at room temperature and rinsed thrice with distilled water. These were then treated with an aqueous $0.1 \%(\mathrm{w} / \mathrm{v}) \mathrm{HgCl}_{2}$ solution and finally washed repeatedly in sterile distilled water under aseptic condition in front of laminar air flow in order to establish maximum contaminant free cultures without affecting percentage of germination.

\section{In vitro shoot bud multiplication}

Surface sterilized seeds were germinated in vitro on Murashige and Skoog's (MS) (21) basal medium supplemented with $3 \%$ sucrose, $0.05 \mathrm{mg} \mathrm{l}^{-1}(\mathrm{w} / \mathrm{v})$ ascorbic acid, and $0.1 \mathrm{mg} \mathrm{l}^{-1}(\mathrm{w} / \mathrm{v})$ glutamine and $0.25 \%(\mathrm{w} / \mathrm{v})$ Gelrite $^{\circledR}$. The $\mathrm{pH}$ of the medium was adjusted to 5.7 before gelling with Gelrite ${ }^{\circledR}(0.25 \% \mathrm{w} /$ v) and for sterilization the media were autoclaved at $121{ }^{\circ} \mathrm{C}$ for $15 \mathrm{~min}$. The culture was maintained in a culture room at $24 \pm 1^{\circ} \mathrm{C}$, under $16 \mathrm{~h}$ photoperiod provided by cool white fluorescent tubes, giving 48 $\mu \mathrm{mol} \mathrm{m} \mathrm{m}^{-2} \mathrm{~s}^{-1}$ photosynthetic photon flux. The different growth regulators used were $0.2 \mathrm{mg} \mathrm{l}^{-1}$ NAA (anapthaleneacetate, $\mathrm{C}_{12} \mathrm{H}_{10} \mathrm{O}_{2}$ ) in combination with $\mathrm{BAP}$ (6-benzylaminopurine, $\mathrm{C}_{15} \mathrm{H}_{11} \mathrm{~N}_{5}$ ) in five different concentrations of $\left(0.5,1.0,1.5,2.0\right.$ and $\left.2.5 \mathrm{mg} \mathrm{l}^{-1}\right)$. The regenerated shoots, after attaining a length of more than $3.0-4.0 \mathrm{~cm}$, were excised and transferred individually to rooting medium. A two-factor experiment was designed to study the effect of NAA (1.0 $\mathrm{mg} \mathrm{l}^{-1}$ ) as well as strength of MS (full and half) media on rooting of in vitro regenerated shoots. Regenerated plants with well developed shoot and root systems were maintained in half MS basal medium for 60 days.

\section{In vitro root culture}

Roots (1.0-2.0 cm in length, $0.1 \mathrm{~g}$ fresh weight) excised from in vitro plants regenerated through shoot bud multiplication, were used as explants for root culture establishment. Media used for in vitro root culture was also MS basal liquid medium supplemented with $3 \%$ sucrose, $0.05 \mathrm{mg} \mathrm{l}^{-1}(\mathrm{w} / \mathrm{v})$ ascorbic acid, and $0.1 \mathrm{mg}$ $\mathrm{l}^{-1}(\mathrm{w} / \mathrm{v})$ glutamine. The growth regulator used for root culture was NAA ( $\alpha$-naphthalene acetic acid) and the research is conducted in factorial design based on Completely Random Design (CRD) consisted of two factors (22). The factors were strength of MS medium (full, half and quarter) and concentrations of NAA (1.0 and $2.0 \mathrm{mg} \mathrm{l}^{-1}$ ). The factorial level combinations $(3 \mathrm{x} 2)$ result in 6 different treatments and each treatment was repeated for three times in five replicates. The $\mathrm{pH}$ of the medium was adjusted to 5.7 using $1 \mathrm{~N}$ Sodium hydroxide $(\mathrm{NaOH})$. The prepared media was taken in conical flasks of $250 \mathrm{ml}$ capacity and $50 \mathrm{ml}$ of liquid media were poured in each conical flask. The culture vessels containing media were autoclaved at $121{ }^{\circ} \mathrm{C}$ for $15 \mathrm{~min}$ and the cultures were maintained in a culture room at $24 \pm 1{ }^{\circ} \mathrm{C}$, under dark condition on a rotary shaker at $150 \mathrm{rpm}$. Subculturing was done after 10 days intervals. 


\section{Addition of elicitor to the root culture}

A biotic elicitor MeJA was used at a wide range of concentrations $(0.01,0.1$ and $1.0 \mathrm{mM})$ during root culture at day 30 of the culture period. Stock solutions of each were prepared in distilled water and were filter sterilized prior to addition to root culture (23). In control media, same volume of water was added instead of elicitor. Biomass content, total phenol and rosmarinic acid contents were analyzed from control tissues and compared with in vivo plants as well as elicitor treated roots after 10 days intervals.
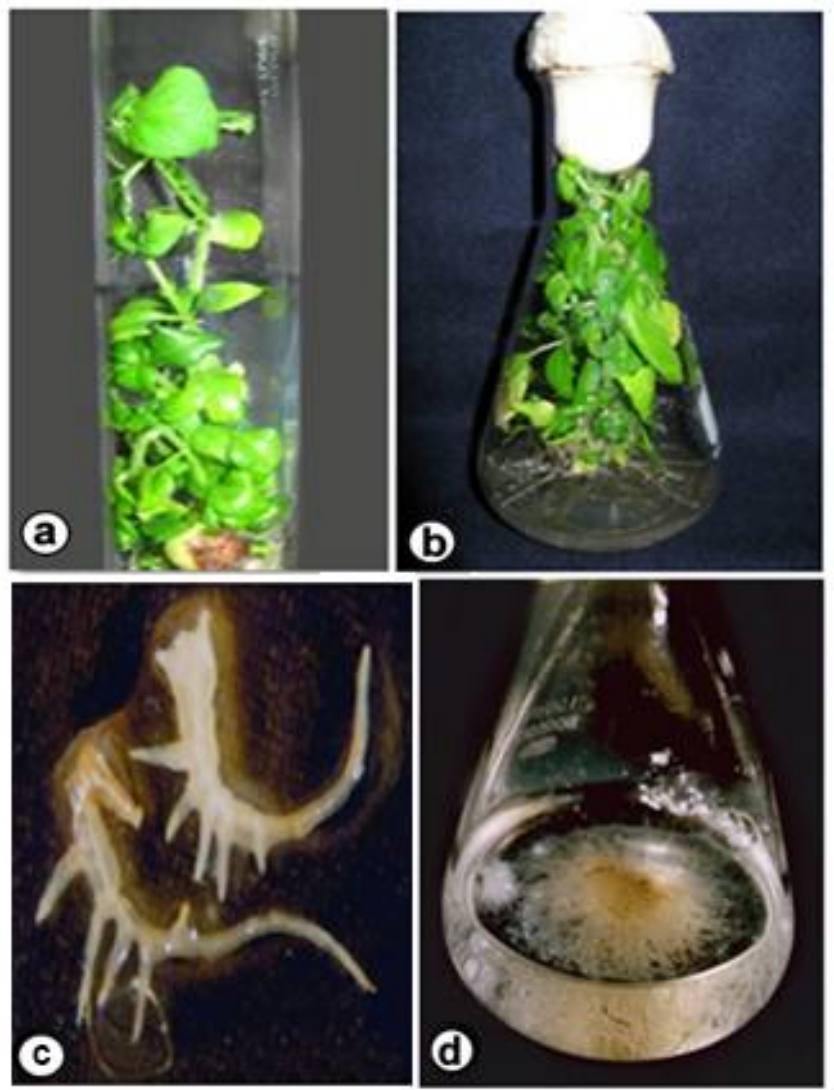

Fig. 2. a. Shoot bud multiplications of $O$. basilicum L. after 8 weeks in culture (NAA $0.2 \mathrm{mg} \mathrm{l}^{-1}$ and BAP $1.5 \mathrm{mg} \mathrm{l}^{-1}$ ) (c.a. x 0.56 ), b. In vitro regenerated plant maintained in half strength of MS basal medium (4 weeks) (c.a. x 0.46$)$, c. In vitro roots in the media M1 (1/4 MS, NAA $1.0 \mathrm{mg} \mathrm{l}^{-1}$, MeJA $0.1 \mathrm{mM}$ ) (c.a. x 2.8), d. In vitro root cultures in the media M1 (1/4 MS, NAA $1.0 \mathrm{mg} \mathrm{l}^{-1}$, MeJA $0.1 \mathrm{mM}$ ) (c.a. x 0.69).

\section{Extraction of phenol including rosmarinic acid}

Roots were harvested aseptically from the culture medium by passing through a stainless steel sieve and were rinsed. After blotting away the surface water roots were wrapped in aluminum foil and allowed to dry in an incubator at $60{ }^{\circ} \mathrm{C}$ temperatures for two weeks. Dried roots were then weighed (g DW/ $50 \mathrm{ml}$ liquid medium) with an electronic pan balance (Sartorius BP1215) (24). Dried plant tissues were used for extraction with aqueous methanol (80:20 absolute methanol: water, w/v) as solvent. Crude extract was prepared for quantitative determination of rosmarinic acid following standard methods $(25,26)$.

\section{Determination of total phenol content}

The total phenol contents were determined using a standard curve prepared with a series of standard solutions of Gallic acid $\left(\mathrm{R}^{2}=0.9987\right)$ equivalents per gram dry weight and expressed as $\mathrm{mg}$ of Gallic acid equivalents per g of dry weight (mg GAE/g DW) (25, 26). For spectrophotometric analysis, $0.5 \mathrm{ml}$ of stock solution $\left(5.0 \mathrm{mg} \mathrm{ml}{ }^{-1}\right)$ was dissolved in $7.0 \mathrm{ml}$ of double distilled water and Folin-Ciocalteu's phenol reagent $(0.5 \mathrm{ml})$ was added to the sample $(29,30)$. A saturated aqueous sodium carbonate solution $(1.0 \mathrm{ml})$ (w/v) was added and volume made up to $10 \mathrm{ml}$ and kept at $18^{\circ} \mathrm{C}$ for $1 \mathrm{~h}$. Dark blue colour was developed, and the absorbance was measured by spectrophotometer (Beckman, UV/Vis) at $720 \mathrm{~nm}$.

\section{Quantification of rosmarinic acid using high performance liquid chromatography (HPLC)}

HPLC (Shimadzu, SPD-10A UV-Vis detector, LC- 10AD Liquid chromatograph) separation was achieved using a C18 column, (150 x $4.6 \mathrm{~mm}$, Hypersil) of particle size $5.0 \mu \mathrm{m}$ and water: acetonitrile $(83: 17 \mathrm{v} / \mathrm{v})$ was used as mobile phase. Ultraviolet detection was set at $330 \mathrm{~nm}$. The temperature and flow rate were set at $30{ }^{\circ} \mathrm{C}$ and $0.5 \mathrm{ml} \mathrm{min}{ }^{-1}$, respectively. (Fig. 2) Rosmarinic acid contents (\% of dry wt) were calculated using a calibration curve (i.e., concentration vs peak area) (31) (Fig. 3).

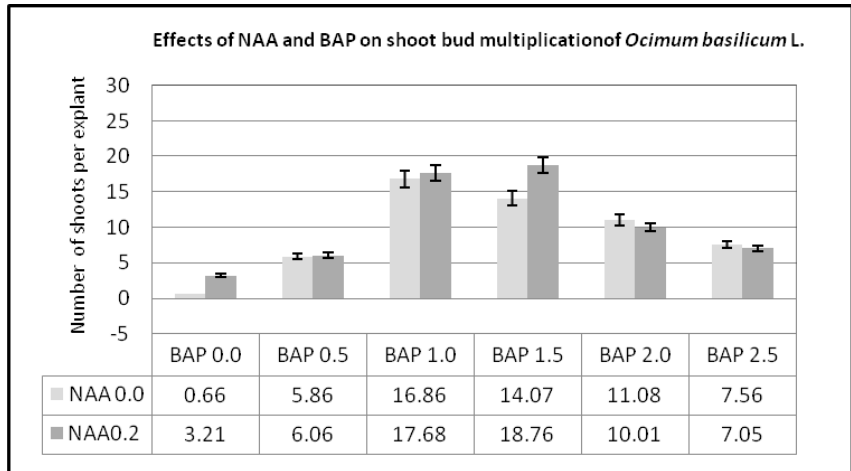

Fig. 3. Effects of NAA $\left(0.0\right.$ and $\left.0.2 \mathrm{mg} \mathrm{l}^{-1}\right)$ and different concentrations of BAP $\left(0.0,0.5,1.0,1.5,2.0\right.$ and $\left.2.5 \mathrm{mg} \mathrm{l}^{-1}\right)$ on shoot bud multiplication of Ocimum basilicum L. (Mean number of shoots per explant up to 8 weeks).

\section{Statistical analysis}

Data were analyzed statistically following one-way ANOVA and two-way ANOVA (32). Statistical analyses were done using SPSS version 15.0 for Windows (SPSS Inc., USA).

\section{Results and Discussion}

In the present investigation an attempt has been made to increase rosmarinic acid content in root cultures of $O$. basilicum L. by using MeJA as an elicitor.

\section{In vitro shoot bud multiplication}

Apical shoot buds from germinated seedling have been found to be suitable explants for in vitro shoot bud multiplication (18.76 \pm 0.317 shoot buds per explant were induced) (Fig. 4). The experiments were conducted to test the effect of different concentrations of BAP $(0.0,0.5,1.0,1.5,2.0$ and 2.5 $\left.\mathrm{mg} \mathrm{l}^{-1}\right)$ either alone or in combination with NAA $(0.2$ $\mathrm{mg} \mathrm{l}^{-1}$ ) in MS medium. In $O$. basilicum L. the average number of shoot buds per explants up to 8 weeks did not varied significantly $(\mathrm{P} \leq 0.05)$ with incorporation 


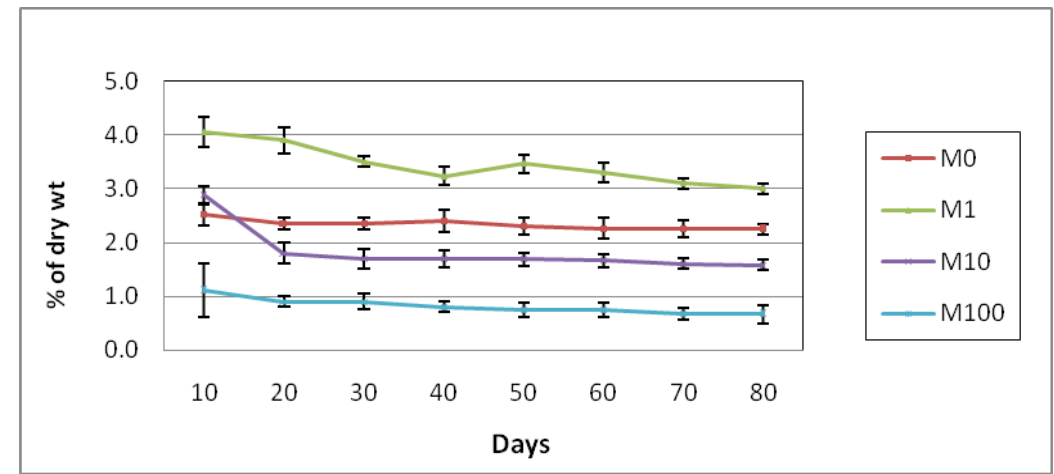

Fig. 4. Accumulation of rosmarinic acid in the roots cultured in the media (1/4 MS supplemented with 1.0 mg $l^{-1}$ NAA) containing different concentrations $(0.01,0.1$ and $1.0 \mathrm{mM})$ of MeJA.

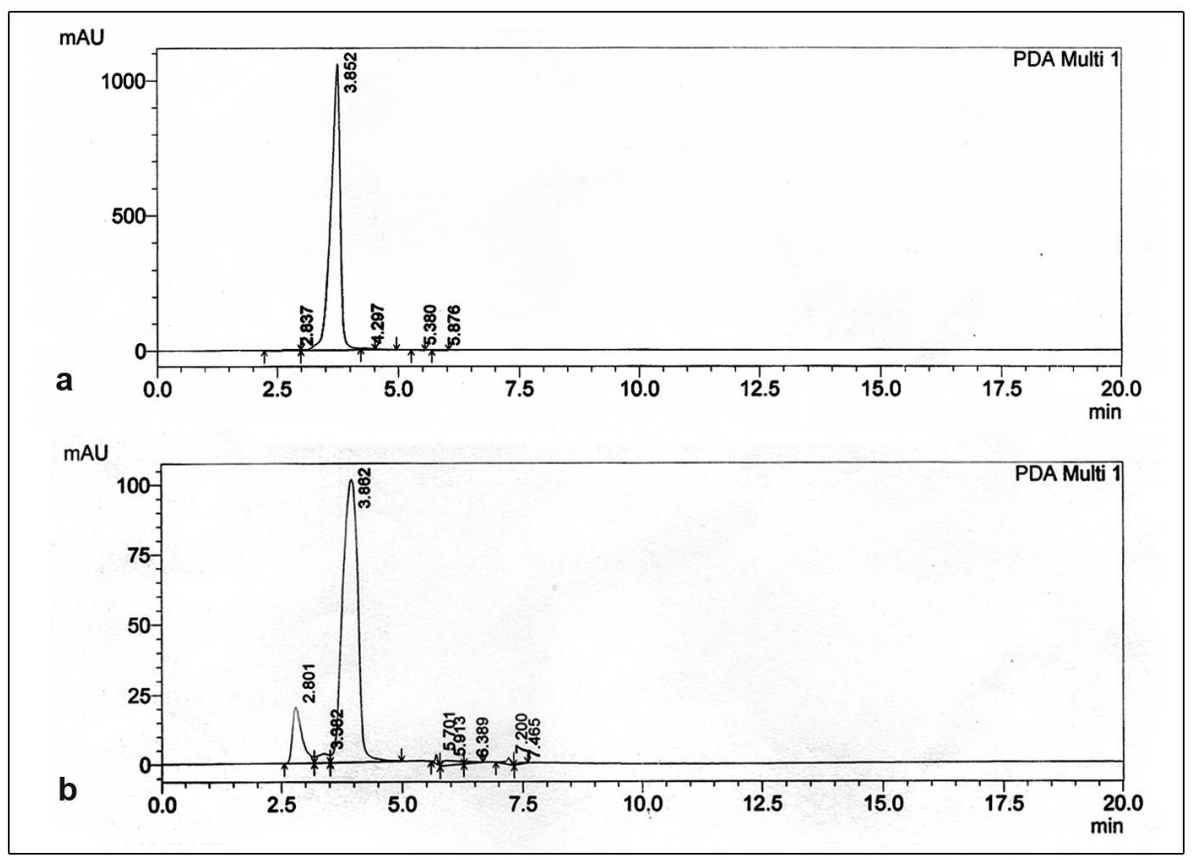

Fig. 5. a. Rosmarinic acid peak (Retention Time $3.852 \mathrm{~min}$ ) of authentic sample of HPLC analysis using C18 column, $(150 \mathrm{x} 4.6 \mathrm{~mm})$ of particle size $5.0 \mu \mathrm{m}$, water: acetonitrile $(83: 17 \mathrm{v} / \mathrm{v})$ as mobile phase, temperature $30^{\circ} \mathrm{C}$, flow rate $0.5 \mathrm{ml} \mathrm{min}^{-1}$ and UV detection at $330 \mathrm{~nm}$; b. Rosmarinic acid peak (Retention Time $3.862 \mathrm{~min}$ ) of extracted sample from in vitro root culture elicited with MeJA, obtained through HPLC analysis in same conditions as that of authentic sample.

of $0.2 \mathrm{mg} \mathrm{l}^{-1} \mathrm{NAA}$ at a fixed level of BAP, except in the media either containing $1.0 \mathrm{mg} \mathrm{l}^{-1}$ or $1.5 \mathrm{mg} \mathrm{l}^{-1} \mathrm{BAP}$ (Fig. 4). All the cultures were maintained up to 16 weeks until the multiplication rate declined. Despite the quantitative variation in number of shoot buds induced, the shoots remained healthy with green leaves and without showing signs of hyper hydricity by the end of the third subculture passage. The shoots showed profuse rooting when transferred to half strength of basal medium (Fig. 5a-b). The analysis of variance of the recorded data revealed that the influence of strength of MS media (full and half) was highly significant $(P<0.0001)$ for number of regenerated shoots rooted though incorporation of auxin (NAA $1.0 \mathrm{mg} \mathrm{l}^{-1}$ ) found to be disadvantageous for rooting of shoots in $O$. basilicum $\mathrm{L}$. but the interaction with strength of MS was found to be highly significant $(\mathrm{P}=0.0001)$.

\section{In vitro root culture}

In vitro root cultures of $O$. basilicum $\mathrm{L}$. was established utilizing different strength of MS basal media (full, half and quarter) with different levels of auxin (1.0 and $\left.2.0 \mathrm{mg} \mathrm{l}^{-1} \mathrm{NAA}\right)$. Roots from in vitro regenerated plants were used to initiate root cultures showing profuse growth (Fig. 5c-d). This attempt was made to establish in vitro root cultures independent of supply of seeds or leaves from in vivo plants throughout the year. There are previous reports of establishment of root cultures of $O$. basilicum $\mathrm{L}$. and $O$. sanctum $\mathrm{L}$. from roots of in vitro geminated seedlings and leaves of in vivo plants $(33,34)$. The initiation and growth of roots on full, half and quarter strength of MS basal media devoid of any growth regulators, remained either non-responsive or poor with maximum $7.80 \pm 0.031 \mathrm{~g}$ DW per $50 \mathrm{ml}$ liquid medium (Table 1) Roots grew very fast (2-5 days) in $1 / 4$ MS media supplemented with NAA $(1.0 \mathrm{mg}$ $\mathrm{l}^{-1}$ and $2.0 \mathrm{mg} \mathrm{l}^{-1}$ ) whereas in $1 / 2$ MS and MS media supplemented with NAA $\left(1.0 \mathrm{mg} \mathrm{l}^{-1}\right.$ and $\left.2.0 \mathrm{mg} \mathrm{l}^{-1}\right)$ took longer time (15-40 days) and even showed rhizogenic callus development in some cases (Table 1). This indicated the necessity of the dilution of MS medium for root culture in liquid media. The increased osmolarity decreased water uptake which in turn reduced growth as well as organ formation. Length of roots was not affected by dilution of media in all the cases, as was evident from non significant $\mathrm{P}$ values (Table 1). Experiment conducted following (35, 36) to determine the effects of media strength (Full 
Table 1. In vitro root cultures of $O$. basilicum L. in liquid media

\begin{tabular}{|c|c|c|c|c|c|}
\hline $\begin{array}{l}\text { MEDIA Strength of MS } \\
+ \text { concentration of NAA } \\
\left(\mathrm{mg} \mathrm{l}^{-1}\right)\end{array}$ & $\begin{array}{c}\text { Day of rooting } \\
\text { initiation }\end{array}$ & No. of roots & $\begin{array}{l}\text { Length of roots } \\
(\mathrm{cm})\end{array}$ & $\begin{array}{l}\text { Biomass increase after } \\
10 \text { days g DW per } 50 \mathrm{ml} \\
\text { medium }\end{array}$ & $\begin{array}{l}\text { Biomass increase } \\
\text { after } 20 \text { days g DW } \\
\text { per } 50 \mathrm{ml} \text { medium }\end{array}$ \\
\hline $\mathrm{MS} / 0.0$ & - & - & - & - & - \\
\hline MS/ 1.0 & $40.2 \pm 0.04$ & $20.01 \pm 2.06$ & $0.76 \pm 0.015$ & - & $0.20 \pm 0.016^{\mathrm{a}}$ \\
\hline MS/ 2.0 & $35.2 \pm 0.11$ & $24.09 \pm 3.22$ & $0.70 \pm 0.012$ & - & $0.26 \pm 0.012^{a}$ \\
\hline $1 / 2 \mathrm{MS} / 0.0$ & - & - & - & - & - \\
\hline $1 / 2 \mathrm{MS} / 1.0$ & $20.5 \pm 0.01$ & $20.11 \pm 4.22$ & $0.80 \pm 0.104$ & - & $1.28 \pm 0.012^{b}$ \\
\hline $1 / 2 \mathrm{MS} / 2.0$ & $15.2 \pm 0.04$ & $24.11 \pm 2.66$ & $0.83 \pm 0.025$ & - & $1.28 \pm 0.021^{\mathrm{b}}$ \\
\hline $1 / 4 \mathrm{MS} / 0.0$ & $5.4 \pm 0.006$ & $20.0 \pm 1.06$ & $0.80 \pm 0.044$ & $7.80 \pm 0.031^{a}$ & $7.40 \pm 0.019^{c}$ \\
\hline $1 / 4 \mathrm{MS} / 1.0$ & $2.0 \pm 0.0$ & $27.0 \pm 2.66$ & $0.80 \pm 0.106$ & $26.00 \pm 0.54^{b}$ & $26.85 \pm 0.037^{d}$ \\
\hline $1 / 4 \mathrm{MS} / 2.0$ & $3.0 \pm 0.0$ & $36.01 \pm 3.01$ & $0.98 \pm 0.101$ & $19.40 \pm 0.024^{\mathrm{c}}$ & $17.63 \pm 0.077^{\mathrm{e}}$ \\
\hline F value & $214.14^{*}$ & $321.451^{*}$ & $0.0003 n s$ & LSD 0.96 & LSD 0.89 \\
\hline
\end{tabular}

à Data represented as mean \pm SE from five replica of an experiment.

${ }^{*} \mathrm{P} \leq 0.05, \mathrm{~ns}=$ non significant $(\mathrm{P}=1.000)(\mathrm{df} 10,44)$

Table 2. The effect of different concentrations of methyl jasmonate (MeJA) (10 days) on root biomass, intracellular total phenol content and rosmarinic acid content of in vitro root cultures of $O$. basilicum L.

\begin{tabular}{|c|c|c|c|c|}
\hline \multirow[b]{2}{*}{$\begin{array}{c}\text { Media } \\
\text { 1/4 } \mathrm{MS}^{+} 1.0 \mathrm{mg} \mathrm{l}^{-1} \\
\text { NAA }\end{array}$} & \multirow[b]{2}{*}{$\begin{array}{l}\text { Concentration of } \\
\text { MeJA } \\
(\mathrm{mM})\end{array}$} & \multicolumn{3}{|c|}{ Average } \\
\hline & & $\begin{array}{c}\text { Root Biomass } \\
\text { (g DW per } 50 \mathrm{ml} \\
\text { medium) }\end{array}$ & $\begin{array}{l}\text { Total Phenol Content } \\
\text { (mg GAE/g DW) }\end{array}$ & $\begin{array}{c}\text { Rosmarinic Acid Content (\% of } \\
\text { dry wt) }\end{array}$ \\
\hline Control & 0.0 & $26.00 \pm 0.54^{\mathrm{a}}$ & $84.83 \pm 0.45^{a}$ & $2.52 \pm 0.31^{a}$ \\
\hline M1 & 0.01 & $26.34 \pm 0.19^{a}$ & $91.71 \pm 0.89^{b}$ & $4.05 \pm 0.74^{b}$ \\
\hline M10 & 0.1 & $20.00 \pm 0.37^{b}$ & $88.73 \pm 0.77^{c}$ & $2.88 \pm 0.10^{a}$ \\
\hline M100 & 1.0 & $7.21 \pm 0.73^{c}$ & $70.87 \pm 0.24^{\mathrm{d}}$ & $1.10 \pm 0.10^{c}$ \\
\hline $\mathrm{LSD}^{* *}$ & & 0.64 & 0.86 & 0.60 \\
\hline
\end{tabular}

à Data represented as mean \pm SE from five replica of an experiment.

** Means followed by different superscript letters in the same column present significant difference $(P \leq 0.05)(\mathrm{df} 3,16)$.

MS, $1 / 2$ MS and $1 / 4$ MS) on roots (number, length) of ginger and spearmint. The results were similar to the ones obtained in our experiment and indicated an increase in root number with the dilution of MS basal medium. Analysis of variance for the recorded data showed that concentrations of NAA (1.0 and $2.0 \mathrm{mg} \mathrm{l}$ $\left.{ }^{1}\right)$ had a high significant $(\mathrm{P}<0.0001)$ effect on biomass content of root cultures. The increase in concentration of NAA from $1.0 \mathrm{mg} \mathrm{l}^{-1}$ to $2.0 \mathrm{mg} \mathrm{l}^{-1}$ significantly decreased the root biomass (Table 1 ) as were also reported in different plant species $(37,38)$.

\section{Increased rosmarinic acid content obtained using methyl jasmonate (MeJA)}

Root cultures were treated with three different concentrations ( $0.01 \mathrm{mM}, 0.1 \mathrm{mM}$ and $1.0 \mathrm{mM}) \mathrm{MeJA}$ during the initial growth phase (30 days) as it was reported to be advantageous for accumulation of inducible compounds (23). Roots have been found to

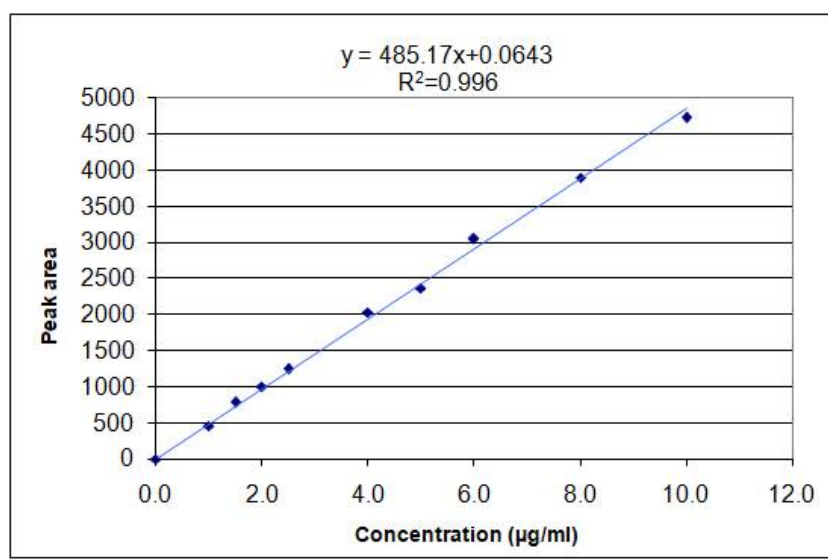

Fig. 6. Calibration curve of standard rosmarinic acid as obtained from HPLC chromatogram. The graph is plotted, peak area against concentration $\left(\mu \mathrm{g} \mathrm{ml}^{-1}\right)$. grow profusely in the media containing elicitor and gradually turned brown after subcultures (Fig. 5d). In the present investigation maximum rosmarinic acid accumulation in sweet basil root cultures occurred after 10 days of addition of elicitor and declined to a linear condition thereafter (Fig. 6). Incorporation of MeJA (0.01 mM, $0.1 \mathrm{mM}$ and $1.0 \mathrm{mM})$ in the media did not favour biomass content in comparison to those in control culture (Table 2). Maximum root biomass (26.34 $\pm 0.19 \mathrm{~g} \mathrm{DW}$ per $50 \mathrm{ml}$ medium) was observed in the media M1 (0.01 mM MeJA) (Table 2) Intracellular phenol as well as rosmarinic acid accumulation of adventitious root culture, was found to increase with the incorporation of MeJA at the concentration $0.01 \mathrm{mM}$ and $0.1 \mathrm{mM}$. Maximum total phenol (91.71 $\pm 0.89 \mathrm{mg} \mathrm{GAE} / \mathrm{g}$ DW) accumulation was observed in the media M1 which was significantly higher $(\mathrm{P} \leq 0.05)$ than control culture (Table 2). Reports are there stating that total amount of phenolic compounds in sweet basil significantly increased after $0.5 \mathrm{mM}$ MeJA treatment (39). Studies are there on accumulation of $33.0 \pm 0.57 \mathrm{mg} \mathrm{GAE} / \mathrm{g}$ DW phenolic content in cell cultures of $O$. basilicum L. when treated with $25 \mu \mathrm{M}$ MeJA (11). Further increase in MeJA concentration $(0.1,1.0 \mathrm{mM})$ in the media (M10 and M100) was not favourable for total phenol and rosmarinic acid accumulations in roots (Table 2). The drop in percentage content of rosmarinic acid was probably the result of rapid growth unmatched by an equally rapid ester deposition (39). Several parameters such as elicitor concentration and selectivity, duration of elicitor exposure, age of culture, growth regulators and nutrient composition has effect on substantial enhancement of product accumulation (40). 
Table 3. Rosmarinic acid contents of in vivo and in vitro regenerated plants of $O$. basilicum $\mathrm{L}$.

Average rosmarinic acid content (\% of dry wt)

\begin{tabular}{crrr} 
Ocimum basilicum & \multicolumn{3}{c}{ (\% of dry wt) } \\
\cline { 2 - 4 } & \multicolumn{1}{c}{ Shoots } & \multicolumn{1}{c}{ Roots } & \multicolumn{1}{c}{ Average } \\
\hline In vivo & $1.59 \pm 0.094$ & $1.44 \pm 0.094$ & $1.51 \pm 0.06$ \\
\hline In vitro & $1.86 \pm 0.060$ & $1.96 \pm 0.160$ & $1.91 \pm 0.09$ \\
\hline F value & 5.97 & 7.78 & 12.79
\end{tabular}

à Data represented as mean \pm SE from five replica of an experiment.

${ }^{*} \mathrm{P} \leq 0.05, \mathrm{~ns}=$ non significant $(\mathrm{df} 1,8)$

The treatment with elicitor molecule, MeJA provided maximum rosmarinic acid accumulation $(4.05 \pm 0.74 \%$ of dry wt) at the concentration 0.01 $\mathrm{mM}$ in M1 medium (1.91 and 2.68 times more than in vitro and in vivo plants respectively) (Table 3). MeJA has been used as effective elicitor in several experiments to enhance secondary metabolites in in vitro cultures. MeJA increases phenyl ammonia lyase (PAL) activity which is the key enzyme of rosmarinic acid biosynthetic pathway (41). Reports are on MeJA as an effective elicitor with the concentration of 0.1 $0.5 \mathrm{mM}$ for production of rosmarinic acid in $O$. basilicum L. (39). Reports are there on the suspension cultures of Coleus blumei (Lamiaceae) treated with MeJA enhanced accumulation of rosmarinic acid approximately 3.0 fold (9). MeJA increased phenyl ammonia lyase (PAL) activity which is the key enzyme of rosmarinic acid biosynthetic pathway (42). The enhancing effect of MeJA on rosmarinic acid contents in the Satureja khuzistanica cell cultures was demonstrated (43). A week of MeJA treatment, the Satureja cells accumulated up to 3.2-fold more rosmarinic acid than the control cells (44). MeJA appears to have an important impact on rosmarinic acid accumulation, and the increased rosmarinic acid accumulation in the treated cells might be due to activation of the phenylpropanoid genes ArPAL, ArC4H, and Ar4CL (45).

\section{Conclusion}

This is the first report of enhancement of rosmarinic acid production in non-transformed root culture of $O$. basilicum L. using MeJA as elicitor. The root cultures of $O$. basilicum L. were established from roots of in vitro regenerated plants and were found to be susceptible to the elicitor used, with variations in the extent of accumulation of secondary metabolite and root biomass. Maximum rosmarinic acid accumulation was observed during the initial growth phase (10 days), thus enabling production during a brief, single stage culture. The treatment with elicitor molecule, methyl jasmonate provided maximum rosmarinic acid accumulation $4.05 \pm 0.74 \%$ of dry $\mathrm{wt}$ (2.68 times more than in vivo plants) at the concentration $0.01 \mathrm{mM}$ (M1 medium). Advances have been made in selecting basils that contain high amount of specific active principle through traditional breeding and selection programs. But achieving resistance to multiple pathogens, pests and breeding for improved active principle content have proven to be a long and harder task. By utilizing the advantages of in vitro root culture, it is conceivable that genes from other sources can be integrated into basil to confer resistance to pathogens and pests that would not only greatly enhance but also stabilize production of various active principles of basil including rosmarinic acid. Therefore, these results open the possibility of implementing biotechnological platform based on elicited root cultures of $O$. basilicum L. for the production of rosmarinic acid.

\section{Author's contribution}

Dr. T. Biswas has done plant tissue culture, extraction of rosmarinic acid, spectrophotometric analysis and high performance liquid chromatography (HPLC), guided and supervised by Dr. Sandip Mukhopadhyay, (Rtd) Professor, Department of Botany, University of Calcutta.

\section{Acknowledgements}

Financial assistance to the author in the form of JRF and SRF (NET) (F. No. 09/028(0639)/2004-EMR-1) from the CSIR, New Delhi is gratefully acknowledged. This work was carried out in the tissue culture laboratory of Professor (Rtd) Dr. Sandip Mukhopadhyay, Department of Botany, University of Calcutta. I would like to thank Dr. Sandip Mukhopadhyay for his immense support to this work including valuable suggestions. I am grateful to Dr. Debabrata Maity, Department of Botany, University of Calcutta for plant identification.

\section{Competing interest}

Authors do not have any conflict of interest to declare.

\section{References}

1. Hiltunen R, Holm Y. Basil: The genus Ocimum. CRC Press, Boca Raton, Florida; 1999

2. Paria ND, Chattopadhayay SP. Flora of Hazaribagh District, Bihar, Vol II. Botanical Survey of India, Kolkata; 2005

3. Chen H, Chen F, Zhang YL, Song JY. Production of lithospermic acid $\mathrm{B}$ and rosmarinic acid in hairy root cultures of Salvia miltiorrhiza. J Ind Microbiol Biotechnol. 1999;22:133-38. https://doi.org/10.1038/sj.jim.2900624

4. Sharmila R, Manoharan S. Antitumor activity of rosmarinic acid in 7, 12- di methyl benz (a) anthracene (DMBA) induced skin carcinogenesis in Swiss albino mice. Ind J Exp Biol. 2012;50:187-94

5. Jayasinghe C, Gotoh N, Aoki T, Wada S. Phenolics composition and antioxidant activity of sweet basil (Ocimum basilicum L.). J Agric Food Chem. 2003;51(15):4442-49. https://doi.org/10.1021/jf034269o

6. Munoz-munoz JL, Garcia -Molina F, Rose E, Tudela J, GarciaCanovas F, Rodriguez - Lopez JN. Prooxidant and antioxidant activities of Rosmarinic acid. J Food Biochem. 2013;37:396-408. https://doi.org/10.1111/j.1745-4514.2011.00639.x

7. Li W, Koike K, Assada Y, Yoshikawa T, Nikaido T. Rosmarinic Acid production by Coleus forskohlii hairy root cultures. Plant Cell Tiss Org Cult. 2005;80:151-55. https://doi.org/10.1007/s11240-004-9541-X

8. Mizukami H, Ogawa T, Ellis BE. Induction of rosmarinic acid biosynthesis in Lithospermum erythrorihizon cell suspension cultures by yeast extract. Plant Cell Rep. 1992;11(9):480-83. https://doi.org/10.1007/BF00232695 
9. Szabo E, Thelen A, Petersen M. Fungal elicitor preparations and methyl jasmonate enhance rosmarinic acid accumulation in cell suspension cultures of Coleus blumei. Plant Cell Rep. 1999;18:485-89. https://doi.org/10.1007/s002990050608

10. Radman R, Saez T, Bucke C, Keshavarz T. Elicitation of plant and microbial systems. Biotech and Applied Biochem. 2003;37:91-102. https://doi.org/10.1042/BA20020118

11. Naik PM, Al-Khayri JM. Abiotic and biotic elicitors-role in secondary metabolites production through in vitro culture of medicinal plants. InTech. 2016;10:247-77. https://doi.org/10.5772/61442

12. Kim H, Chen F, Wang X, Rajapakse NC. Effect of methyl jasmonate on secondary metabolites of sweet basil (Ocimum basilicum L.). J Agric Food Chem. 2006;54(6):2327-32. https://doi.org/10.1021/jf051979g

13. Mathew R, Sankar PD. Effect of methyl jasmonate and chitosan on growth characteristics of Ocimum basilicum L., Ocimum sanctum L. and Ocimum gratissimum L. cell suspension cultures. Afr J Biotechnol. 2012;11(21):4759-66. https://doi.org/10.5897/AJB11.3183

14. Shetty K. Biotechnology to harness the benefits of dietary phenols: focus on Lamiaceae. Asia Pacific J Clin Nutr. 1997;6:162-71

15. Simon JE, Quinn J, Murray RG. Basil: a source of essential oils. In: Janick J, Simon J E, editors. Advances in New Crops. Portland: Timber Press; 1990. p 484-89

16. Kirtikar KR, Basu BD. Indian Medicinal Plants with Illustrations. Oriental Enterprises, Uttaranchal, India, 2003; vol VIII, p. 2701-05

17. Khare CP. Indian Medicinal Plants, An Illustrated Dictionary. Springer India (P) Ltd, New Delhi, India, 2007;442-44p. https://doi.org/10.1007/978-0-387-70638-2

18. Ramachandra Rao S, Ravishankar GA. Plant cell cultures: Chemical factories of secondary metabolites. Biotechnol Adv. 2002;20:101-53. https://doi.org/10.1016/S0734-9750(02)00007-1

19. Oksman-Caldentey KM, Inzé D. Plant cell factories in the postgenomic era: new ways to produce designer secondary metabolites. Trends Plant Sci. 2004;9:433-40. https://doi.org/10.1016/j.tplants.2004.07.006

20. Discosmo F, Misawa M. Eliciting secondary metabolism in plant cell cultures. Trends Biotechnol. 1985;3:318. https://doi.org/10.1016/0167-7799(85)90036-8

21. Murashige T, Skoog F. A revised medium for rapid growth and bioassays with tobacco tissue cultures. Physiol Plant. 1962; 15:472-97. https://doi.org/10.1111/j.1399-3054.1962.tb08052.x

22. Hinkelmann $\mathrm{K}$, Kempthorne O. Design and Analysis of Experiments, Vol. 1, Introduction to Experimental Design. $2^{\text {nd }}$ Ed., Wiley and Sons Inc, Hoboken, New Jersey; 2007. https://doi.org/10.1002/9780470191750

23. Ghosh S, Ghosh B, Jha S. Aluminum chloride enhances colchicine production in root cultures of Gloriosa superba. Biotech Lett. 2006;28:497-503. https://doi.org/10.1007/s10529006-0004-9

24. Wu CH, Hosakatte HN, Hanh EJ, Paek KY. Establishment of adventitious root co-culture of Ginseng and Echinacea for the production of secondary metabolites. Acta Physiol Plant. 2008; 30:891-96. https://doi.org/10.1007/s11738-008-0181-3

25. Ellis BE, Towers GHN. Biogenesis of rosmarinic acid in Mentha Biochem J. 1970; 118:291-97. https://doi.org/10.1042/bj1180291

26. Didier JG, Pasquier BP. Analysis and distribution of flavonoid glycosides and rosmarinic acid in 40 Mentha $x$ piperita clones. J $\begin{array}{lll}\text { Agric } & \text { Food } \quad \text { Chem. } & \text { 1994;42:679-84. }\end{array}$ https://doi.org/10.1021/jf00039a015

27. Singleton VL, Orthofer R, Lamuela-Raventos RM. Analysis of total phenols and other oxidation substrates and antioxidant by means of Folin-Ciocalteu reagent. Methods Enzymol. 1999; 299:152-78. https://doi.org/10.1016/S0076-6879(99)99017-1
28. Javanmardi J, Khalighi A, Kashi A, Bais HP, Vivanco JM. Chemical characterization of basil (Ocimum basilicum L.) found in local accessions and used in traditional medicines in Iran. J Agric Food Chem. 2002;50(21):5878-83. https://doi.org/10.1021/jf020487q

29. Folin O, Ciocalteau VJ. On Tyrosine and Tryptophan determinations in proteins. J Biol Chem. 1927;73:627-50

30. Spanos GA, Wrolstad RE. Influence of processing and storage on the phenolic composition of Thompson seedless grape juice. J Agric Food Chem. 1990;38:1565-71. https://doi.org/10.1021/jf00097a030

31. Hernandez F, Madrid J, Garcia V, Orengo J, Megias MD Influence of two plants extracts on broilers performance, digestibility, and digestive organ size. Poultry Sci. 2004;83:16974. https://doi.org/10.1093/ps/83.2.169

32. Sokal R, Rohlf FJ. Introduction to Biostatistics. $2^{\text {nd }}$ ed. $W H$ Freeman (ed.) New York; 1987

33. Tada $\mathrm{H}$, Ikeda $\mathrm{Y}$, Omoto $\mathrm{T}$, Shimomura $\mathrm{K}$, Ishimaru $\mathrm{K}$ Rosmarinic acid and related phenolics in adventitious root cultures of Ocimum basilicum L. Plant Tiss Cult Lett. 1996; 13:69-71. https://doi.org/10.5511/plantbiotechnology1984.13.69

34. Shilpa K, Selvakkumar C, Senthil AK, Lakshmi S. In vitro root culture of Ocimum sanctum L. and evaluation of its free radical scavenging activity. Plant Cell Tiss Org Cult. 2010;101:105-09. https://doi.org/10.1007/s11240-009-9661-4

35. Villamor CC. Influence of media strength and sources of nitrogen on micropropagation of ginger, Zingiber officinale Rosc. E-Int Sci Res J. 2010; 2:50-55

36. Fadel D, Kintzios S, Economou AS, Moschopoulou G Constantinidou HIA. Effect of different strength of medium on organogenesis, phenolic accumulation and antioxidant activity of spearmint (Mentha spicata L.). The Open Hort J. 2010;3:31 35. https://doi.org/10.2174/1874840601003010031

37. Wu CH, Dewir YH, Hanh EJ, Paek KY. Optimization of culturing conditions for the production of biomass and phenolics from adventitious roots of Echinacea angustifolia. J Plant Biol 2006;49(3):193-99. https://doi.org/10.1007/BF03030532

38. Jenifer $\mathrm{U}$, Francina Cecilia $\mathrm{K}$, Ravindhran $\mathrm{R}$. In vitro adventitious root and hairy root cultures in Boerhaavia diffusa L. Int J Curr Res. 2012;49(1):65-67

39. Razzaque A, Ellis BE. Rosmarinic acid production in Coleus cell cultures. Planta. https://doi.org/10.1007/BF00388164

1977:137:287-91

40. Patel H, Krishnamurthy R. Elicitors in Plant Tissue Culture. J Pharmacog Phytochem. 2013; 2:60-65

41. Li Z, Wang X, Chen F, Kim HJ. Chemical changes and over expressed genes in Sweet Basil (Ocimum basilicum L.) upon methyl jasmonate treatment. J Agric Food Chem. 2007;55(3):706-13. https://doi.org/10.1021/jf062481x

42. Petersen M, Haeusler E, Meinhard J, Karwatzki B, Gerlowski C. The biosynthesis of rosmarinic acid in suspension cultures of Coleus blumei. Plant Cell Tiss Org Cult. 1993;38:171-79. https://doi.org/10.1007/BF00033875

43. Khojasteh A, Mirjalili MH, Hidalgo D, Corchete P. New trends in biotechnological production of rosmarinic acid. Biotechnol. Lett. 2014;36:2393-406. https://doi.org/10.1007/s10529-0141640-0

44. Khojasteh A, Mirjalili MH, Palazon J, Eibl R, Cusido RM. Methyl jasmonate-enhanced production of rosmarinic acid in cell cultures of Satureja khuzistanica in a bioreactor. Eng. Life Sci. 2016;16:740-49. https://doi.org/10.1002/elsc.201600064

45. Kim YB, Kim JK, Uddin MR, Xu H. Metabolomics analysis and biosynthesis of rosmarinic acid in Agastache rugosa Kuntze treated with methyl jasmonate. PloS One. 2013;8,e64199. https://doi.org/10.1371/journal.pone.0064199 